\title{
Basson unrepentant as drawn-out sentencing argument begins
}

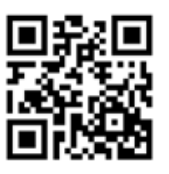

Despised apartheid-era chemical warfare expert Dr Wouter Basson, dubbed 'Dr Death' by his detractors and currently practising as a highly respected cardiologist in Durbanville, Cape Town, failed to show that he even 'reflected on the possibility that he violated medical ethics'.

This was said by Dr Marjorie Jobson, director of the support group for victims of apartheid Khulumani, in aggravation of sentence at the end of November 2014, just over 11 months after Basson, aged
65, was found guilty of unprofessional conduct by a Health Professions Council of South Africa (HPCSA) inquiry. The inquiry, by a committee of the Medical and Dental Professions Board headed by Prof. Jannie Hugo, found that the unrepentant cardiologist violated basic 


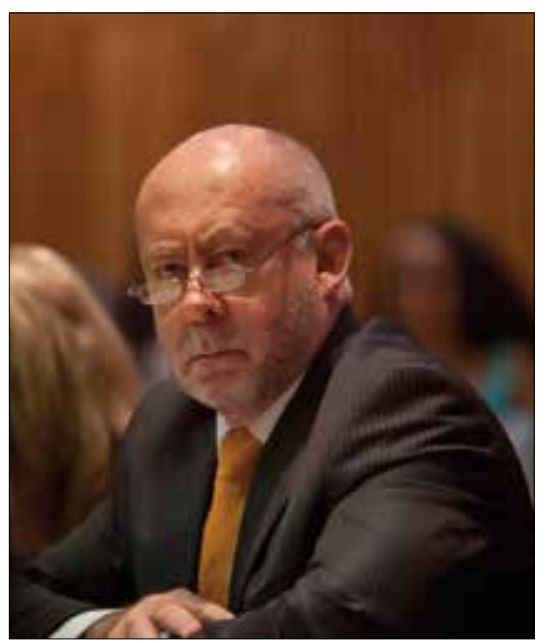

Cardiolgist and chemical warfare expert Dr Wouter Basson.

medical ethics, which they described as 'especially important in times of war and conflict', and defiled the 'unique and sacred position' of trust in doctors by society that impelled them to stay true to the ethical values of 'beneficence, nonmalificence, justice and autonomy'. Basic medical ethics had not changed since the time of the offences.

The committee found that Basson, while project officer of Project Coast and its military front teargas and drugs manufacturing company, Delta G, in the late 1980s and early 1990s, co-ordinated the production and stockpiling of Mandrax, ecstasy and teargas on a major scale and provided 'disorientating substances for cross-border kidnapping. He also supplied cyanide suicide capsules to apartheid undercover operatives for use if captured. Under the instructions of the chief of the Defence Force, Basson weaponised thousands of $120 \mathrm{~mm}$ mortars with teargas for use by Jonas Savimbi's National Union for the Total Independence of Angola (Unita) forces that South Africa abortively backed in the 1980s, committing troops and heavy weaponry to fight the Cuban-backed MPLA in Angola.

Basson, in testimony prior to his acquittal on related criminal charges in the High Court in Pretoria - and subsequent failed state appeal bids to the Supreme Court of Appeal and the Constitutional Court (ending in 2005) - has insisted that his now confirmed unprofessional conduct came within the context of war and conflict and that no proof was ever obtained that he caused harm or death. Dr Jobson said that Basson neglected core medical ethics and failed to exercise his choice in support of them. She backed a petition from leading medical professional and human rights bodies, including the South African Medical Association, calling for his striking from the roll and harsh sanction. The petition was presented during the sentencing hearing by Mark Heywood, executive director of the activist organisation Section 27, amid dramatic contestation and attempts at ridicule by Basson's defence counsel, Japie Cilliers, SC.

\section{Strong sanctions prompt remorse - De Kock an example}

Jobson testified that 'in theory he [Basson] can say that his activities did not have lethal consequences ... it is only out of the reality of sanctioning his behavior that there is any reflection on what their perpetrators caused on the citizens of South Africa. Eugene De Kock [the jailed governmentsanctioned apartheid-era covert Vlakplaas murder squad chief] is a prime example.' She said sanction created the opportunity for reflection and accepting responsibility. 'Without it, we never get to a point where people consider that perhaps their activities were not in the best interest of the country and the majority of the people, she added. Asked by Cilliers whether she was appealing to the hearing to pass a harsh sentence so that the cardiologist would show remorse, Jobson said a punitive sentence would be 'fitting. 'Everywhere in the world where I go, the first question which arises is how is it possible that $\mathrm{Dr}$ Basson has never been sanctioned up to now? People cannot comprehend that. We believe that his practice needs a very severe sanction. The problem is that Dr Basson has not conceded ... he has not shown that he has reflected on the possibility that he violated medical ethics. He has not taken responsibility.'

\section{Basson's 'no killing, no harm' defence dubious - witness}

Jobson described Basson's claims that his activities were non-lethal as 'dubious'. 'Khulumani has a membership of 6800 families of the disappeared people who were abducted in operations by the security police using [chemical] agents.'

Heywood went head-to-head with Cilliers after reading out the petition signed by 230 doctors and top medical and human rights bodies demanding Basson's deregistration as a doctor. Cilliers described 230 signatures out of 39000 available doctors as 'insignificant', suggesting that this actually meant that the majority of doctors supported Basson. He described Heywood as a 'layman and administrator of petitions', accusing him of using the hearing as a platform to promote his Section 27 NGO. Heywood shot back, 'I am a rights bearer and a consumer of healthcare, adding that the issue of ethics did not reside only with professionals but with 'everyone else'. Heywood said the Constitution under the new dispensation allowed him to question the activities of anyone he chose to, accusing Cilliers of not understanding the nation's most fundamental legal document. To suggest that the signatory numbers were insignificant was profoundly mistaken and disrespectful of some of the country's leading medical academics, researchers and representative bodies. To Cilliers' rebuttal that he was 'talking numbers', Heywood replied, 'I am talking names'.

\section{Disgrace to the medical profession - HPCSA}

In initial sentencing argument, pro forma prosecutor Sallie Joubert told the Pretoria hearing that Basson acted in a manner disgraceful to the medical profession. 'We will argue that his conduct [during the apartheid era] amounts to disgraceful conduct and that he is a disgrace to the medical profession.' Joubert submitted that the appropriate penalty would be to strike Basson from the register of medical professionals - and for him to pay the (substantial, but as yet unquantified) costs of the lengthy HPCSA inquiry into his conduct.

Among those present during the sentencing argument were members of the Khulumani victims support group, including a Mamelodi mother who lost her 17-yearold ANC exile son in a security police 'dirty tricks' operation.

Argument in mitigation of sentence will be heard in January, with a further postponement to March probable for actual sentencing.

\section{Chris Bateman}

chrisb@hmpg.co.za

S Afr Med J 2015;105(1):9-10.

DOI:10.7196/SAMJ.9222 